\title{
Solid State Fermentation Parameters Effect on Cellulase Production from Empty Fruit Bunch
}

\author{
Vita Wonoputri*, Subiantoro, Made Tri Ari Penia Kresnowati, Ronny Purwadi \\ Department of Chemical Engineering, Faculty of Industrial Technology, Institut Teknologi Bandung, \\ Ganesa 10, Bandung 40132, Indonesia
}

Received: $14^{\text {th }}$ December 2017; Revised: $29^{\text {th }}$ July 2018; Accepted: $3^{\text {rd }}$ August 2018; Available online: $24^{\text {th }}$ October 2018; Published regularly: December 2018

\begin{abstract}
In this study, agriculture waste palm empty fruit bunch (EFB) was used as carbon/cellulose source in solid state fermentation for cheaper cellulase production. Fermentation operation parameters such as solid to liquid ratio, temperature, and $\mathrm{pH}$ were varied to study the effect of those parameters towards crude cellulase activity. Two different fungi organisms, Trichoderma viride and Trichoderma reesei were used as the producers. Extracellular cellulase enzyme was extracted using simple contact method using citrate buffer. Assessment of the extracted cellulase activity by filter paper assay showed that Trichoderma viride is the superior organism capable of producing higher cellulase amount compared to Trichoderma reesei at the same fermentation condition. The optimum cellulase activity of $0.79 \mathrm{FPU} / \mathrm{g}$ dry substrate was obtained when solid to liquid ratio used for the fermentation was 1:1, while the optimum fermentation temperature and $\mathrm{pH}$ were found to be $30{ }^{\circ} \mathrm{C}$ and 5.5 , respectively. The result obtained in this research showed the potential of EFB utilisation for enzyme production. Copyright $\mathbb{C}$ 2018 BCREC Group. All rights reserved
\end{abstract}

Keywords: Cellulase; Empty Fruit Bunch; Trichoderma; Solid State Fermentation

How to Cite: Wonoputri, V., Subiantoro, Kresnowati, M.T.A.P., Purwadi, R. (2018). Solid State Fermentation Parameters Effect on Cellulase Production from Empty Fruit Bunch. Bulletin of Chemical Reaction Engineering \& Catalysis, 13 (3): 553-559 (doi:10.9767/bcrec.13.3.1964.553-559)

Permalink/DOI: https://doi.org/10.9767/bcrec.13.3.1964.553-559

\section{Introduction}

The high demand for cellulase originated from its wide application in pulp and paper, textile, food and beverages, detergent and animal feed industries, highlighting the importance of cellulase as the third largest industrial enzyme in the world enzyme market [1]. Furthermore, the increasing need for alternative renewable energy source is forecasted to further increase cellulase demand, due to its ability to break down cellulose in lignocellulosic materials, such

\footnotetext{
* Corresponding Author.

E-mail: vita@che.itb.ac.id (V. Wonoputri)

Telp: +62-22-2500989, Fax: +62-22-2501438
}

as agricultural waste, into smaller sugar units, such as cellobiose and glucose, that is useful for bioethanol fermentation and subsequent fine chemical production [1,2]. In fact, the successful utilisation of cellulosic/lignocellulosic materials for the production of second/third generation biofuel is highly affected by cellulase production cost $[3,4]$. It was calculated that cellulase cost accounts for $\sim 40 \%$ of the total bioethanol cost $[5,6]$. Therefore, further research on cheaper cellulase production is needed.

Commercial cellulase is normally produced using submerged fermentation method, which requires high energy and costly purification process $[1,6]$. On the other hand, solid state fermentation, whereby microorganism were grown 
on solid subtrate in the absence of free flowing water [5], becomes an attractive alternative due to its high productivity, lower energy requirement, and simpler purification process [1], [6]. The enzymes produced from solid state fermentation were reported to be less susceptible to inhibition and have better stability to temperature and $\mathrm{pH}$ change [7]. Another advantage of this method is the possibility to use agricultural waste as carbon source and cellulase production inducer [7], thus able to suppress the cost of carbon source, which accounts for more than $50 \%$ of the total enzyme cost if it were pure glucose [2]. Indonesia, which is the largest producer of palm oil in the world, produce millions of tons agricultural lignocellulosic waste in the form of palm empty fruit bunch (EFB) [8]. EFB holds a potential to be used as the sole carbon source in solid state cellulase fermentation, as shown in other literature [810]. However, in developing this process, it is important to examine the effect of fermentation operation parameters, specifically incubation duration, $\mathrm{pH}$, temperature, and moisture level $[1,11]$.

Therefore, in this study, we investigated the effects of several fermentation operation parameters, namely solid to liquid medium ratio (moisture level), temperature, and $\mathrm{pH}$ for cellulase production using solid state fermentation method. Two fungi organism, namely Trichoderma viride (TV) and Trichoderma reesei (TR), were used for extracellular cellulase production and the effects of the producer species towards cellulase activity was also studied. The information obtained would be useful for the development of cellulase production process from the ubiquitous EFB in Indonesia.

\section{Materials and Methods}

\subsection{Enzyme Synthesis}

EFB was obtained from PT Perkebunan $\mathrm{Na}$ sional 8 in Bogor, Indonesia. Typical composition of EFB consist of (\%w/w): $33 \%$ cellulose, $29 \%$ hemicellulose, $21 \%$ lignin [12]. Before use, EFB was thoroughly cleaned and dried for 24 hours at $80^{\circ} \mathrm{C}$. EFB was then cut to $0.5-1$ $\mathrm{cm}$ pieces and kept in a dry container.

Trichoderma viride QM9414 (TV) and Trichoderma reesei QM9414 (TR) were used for extracellular cellulase production. The microbes were grown on potato dextrose agar (Oxoid Ltd.) slants and re-cultured every 7 days. To prepare the spore suspension, $6 \mathrm{~mL}$ of $0.9 \% \mathrm{NaCl}$ were added into each agar slants followed by subsequent addition of the aliquots $\left(1 \mathrm{~mL} ; 9-11 \times 10^{6}\right.$ spores) into Erlenmeyer flask containing 5 gram of dried EFB. Each flask were supplied with additional nutrients as developed by Chahal [13] with slight modification. The stock solution contained the following

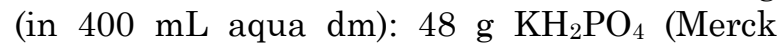
$\mathrm{KgaA}) ; 39.2 \mathrm{~g}\left(\mathrm{NH}_{4}\right)_{2} \mathrm{SO}_{4}($ Merck KgaA); $8.4 \mathrm{~g}$ urea (PT. Brataco Chemika); $8.4 \mathrm{~g}$ $\mathrm{MgSO}_{4} .7 \mathrm{H}_{2} \mathrm{O}$ (Merck KgaA); $8.4 \mathrm{~g} \mathrm{CoCl}_{2}$ (Wako Pure Chemical Industry); $76.54 \mathrm{mg} \mathrm{FeSO}_{4}$ (Hopkin \& Williams Ltd.); $26.65 \quad \mathrm{mg}$ $\mathrm{MnSO}_{4} \cdot \mathrm{H}_{2} \mathrm{O}$ (BDH Chemical Ltd); $39.2 \mathrm{mg}$ $\mathrm{ZnSO}_{4} .7 \mathrm{H}_{2} \mathrm{O}$ (Merck KgaA); $56 \mathrm{mg} \mathrm{CaCl}_{2}$ (Merck KgaA); and $14 \mathrm{~g}$ yeast extract (Oxoid Ltd), yielding final $\mathrm{pH}$ of 5.5.

The parameters studied in this paper are solid to liquid medium ratio (moisture level), temperature, $\mathrm{pH}$ and length of incubation. Two variations of solid to liquid ratio were used, i.e. 1:1 (5 mL; moisture level $50 \%)$ and 1:4 $(20 \mathrm{~mL}$; moisture level $80 \%$ ). Fermentation temperature were varied by incubating the flasks at room temperature (no temperature control), 30 ${ }^{\circ} \mathrm{C}$ and $37^{\circ} \mathrm{C}$. For $\mathrm{pH}$ variation, the stock nutrient $\mathrm{pH}$ of 5.5 were adjusted using either $1 \mathrm{M}$ $\mathrm{HCl}$ or $\mathrm{NaOH}$ yielding final $\mathrm{pH}$ of 4.5 and 6.5. All flask were incubated for 3,5 , and 7 days.

\subsection{Enzyme Extraction and Analysis}

Extracellular cellulase enzyme was extracted using simple contact method. Citrate buffer (50 mM, pH 4.8, $8 \mathrm{~mL} / \mathrm{g}$ dry substrate) were added into each flask, followed by incubation at $30{ }^{\circ} \mathrm{C}, 150 \mathrm{rpm}$, for 2 hours. The suspension was filtered and centrifuged at $4{ }^{\circ} \mathrm{C}, 6000 \mathrm{rpm}$ for $15 \mathrm{~min}$. The supernatants were analyzed by filter paper assay method following the procedure published by National Renewable Energy Laboratory $[14,15]$. In brief, a diluted extracted enzyme was used to hydrolyze $50 \mathrm{mg}$ Whatman No. 1 filter paper at $50{ }^{\circ} \mathrm{C}$ for 60 minutes. The amount of reducing sugar liberated was measured using dinitrosalicylic acid (DNS) method using glucose as the standard. Enzyme activity is expressed as filter paper units (FPU) per gram dry substrate (g DS), where $1 \mathrm{FPU} / \mathrm{g}$ DS is equal to $7.96 \mathrm{FPU} / \mathrm{mL}$. FPU/mL is defined as the amount of enzyme that produced $2 \mathrm{mg}$ of reducing sugar during hydrolysis. Note that filter paper assay only allows the measurement of total cellulase activity, therefore the exact concentration of each type of cellulase could not be determined.

\section{Results and Discussion}

Solid state fermentations for cellulases production were performed using empty fruit bunch (EFB), which is known as a hygroscopic 
lignocellulosic material [16]. Indeed, direct observation during experiment showed that the addition of $5 \mathrm{~mL}$ (ratio of 1:1) or $20 \mathrm{~mL}$ (ratio of 1:4) barely resulted in any significant wetting of the solid medium. Analysis of the enzyme activity was performed at the third, fifth and seventh day. It was reported that production of cellulase reached the maximum level after 5-8 days of incubation [17]. Our previous study using rice straw also showed that at incubation period longer than 7 days, i.e. 10 days, resulted in lower final cellulase activity (result not shown). Therefore, 7 days of incubation was chosen as the maximum, and the result showed that the highest enzyme activity was obtained at the longest incubation period (Figure 1). The highest cellulase activity of $0.79 \mathrm{FPU} / \mathrm{g}$ DS was obtained when TV was used as the producer organism after 7 days incubation at solid to liquid ratio of $1: 1$. Similarly, the maximum cellulase activity for TR (0.61 FPU/g DS) was obtained when fermentation was performed for 7 days with solid to liquid ratio of $1: 1$. Cellulase produced by TV is slightly higher than TR, showing that TV is a more superior cellulase producer as reported before [18].

Increasing the nutrient volume to $20 \mathrm{~mL}$, i.e. increasing the amount of nutrient added and moisture level, led to reduced cellulase yield at the end of 7 days incubation, both for TV and TR systems. Nutrient effect such as nitrogen and phosphorus source or nitrogen, phosphorus and trace element concentration, is known to be a less significant factor compared to moisture level [19-21]. Therefore, this reduction in cellulase yield was most likely caused by difference in moisture level. TR is known to prefer lower moisture level [19,22], as high moisture content resulted in the filling of substrate voids with water, subsequently limiting oxygen access for the microorganism [23,24]. The impact of moisture level on TV is not known yet, however, remembering that both of the organisms are classified under the same genus, it is highly likely that TR has the same preference. Interestingly, the ratio of 1:4 resulted in higher cellulase activity than 1:1 ratio after 5 days incubation in TV system, followed by a decrease in the cellulase yield after 7 days incubation. This suggests that faster production in cellulase does not necessarily resulted in higher cellulase production at the end. It seems that high initial moisture level would allowed TV to grow quickly, consequently releasing significant heat from rapid metabolic activity. This heat would be accumulated inside the substrate bed due to high moisture level in the system. Such unfavorable condition would halt TV growth and trigger sporulation event, therefore stopping cellulase production. On the other hand, slower TV growth on low moisture level would allow heat of metabolic activity to dissipate, allowing the TV to grow steadily and higher final cellulase production could be achieved [25]. Overall, low moisture level of $50 \%$ was found to be the better condition here.

Using the obtained optimum ratio solid to liquid of $1: 1$, the experiment was continued by varying incubation temperature. Solid state fermentation is typically operated at temperature range of $25-35^{\circ} \mathrm{C}$ [26], depends on the mi-
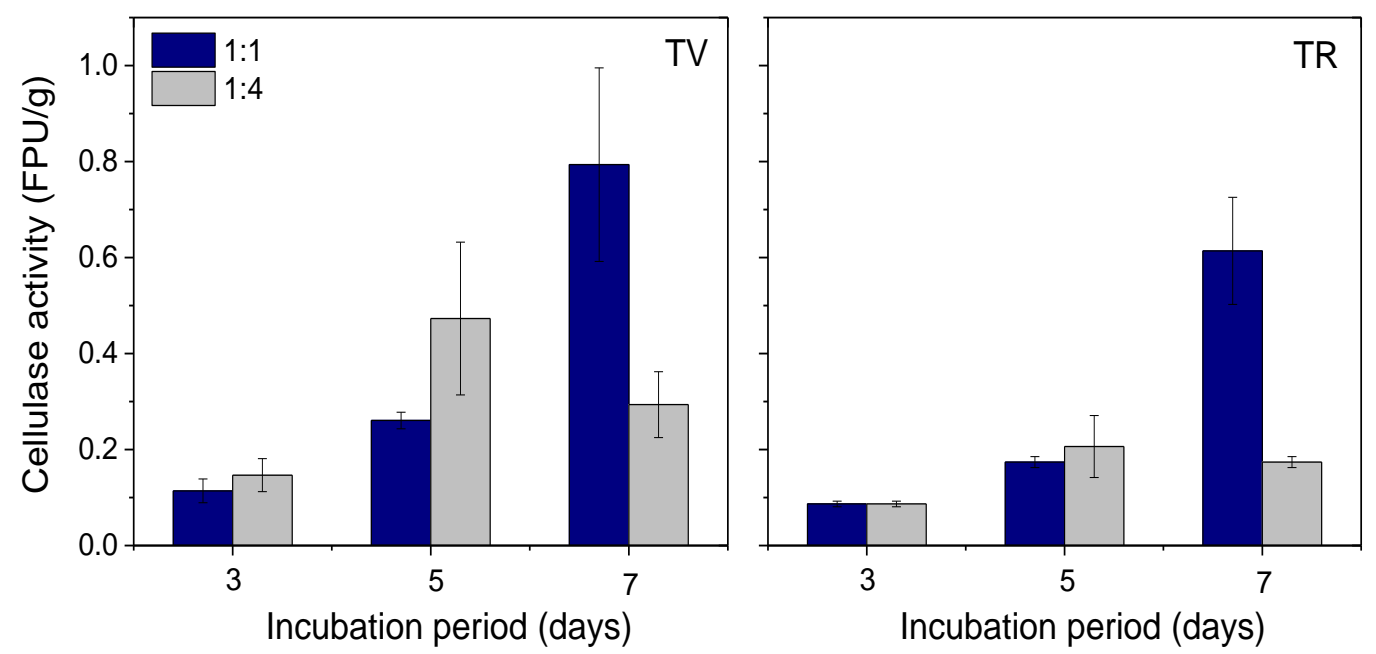

Figure 1. Cellulase activity measurement at different incubation period and different solid to solution ratio for TV (left) and TR (right). Initial nutrient solution $\mathrm{pH}$ was 5.5 and incubation was performed at $30{ }^{\circ} \mathrm{C}$. Error bars indicate standard error between replicates $(n=3)$. 
croorganism used. It was reported that optimal cellulase production was obtained for TR when the operating temperature was within $25-28^{\circ} \mathrm{C}$ [17], while TV can resist a slightly higher temperature of $31-35{ }^{\circ} \mathrm{C}$ [27]. Comparable with other literature, in this research, the maximum cellulase activity was observed when both organisms was incubated at $30{ }^{\circ} \mathrm{C}$ for 7 days, yielding cellulase activity of $0.79 \mathrm{FPU} / \mathrm{g} \mathrm{DS}$ for TV and 0.61 FPU/g DS for TR (Figure 2). When the incubation was performed without any temperature control, the highest cellulase activity for TV and TR were only 0.27 FPU/g DS and $0.23 \mathrm{FPU} / \mathrm{g} \mathrm{DS}$, respectively, which is less than half of that in the optimum temperature. Similarly, when incubation was done at the highest temperature tested here, the cellulase activities were similar to that without temperature control.

The effect of $\mathrm{pH}$ in cellulase production was investigated by changing the $\mathrm{pH}$ of solution used as additional nutrients for fermentation. The initial $\mathrm{pH}$ medium of 5.5 was adjusted to 4.5 and 6.5. Again, the highest cellulase activity was obtained after 7 days incubation with TV (0.79 FPU/g DS) compared to TR (0.61 FPU/g DS). The result (Figure 3 ) showed that the highest cellulase activity was obtained when the nutrient $\mathrm{pH}$ is 5.5. At lower $\mathrm{pH}$ of 4.5, the obtained activities were slightly lower at $0.59 \mathrm{FPU} / \mathrm{g}$ DS and $0.47 \mathrm{FPU} / \mathrm{g} \mathrm{DS}$ for TV and TR, respectively. On the other hand, at $\mathrm{pH}$
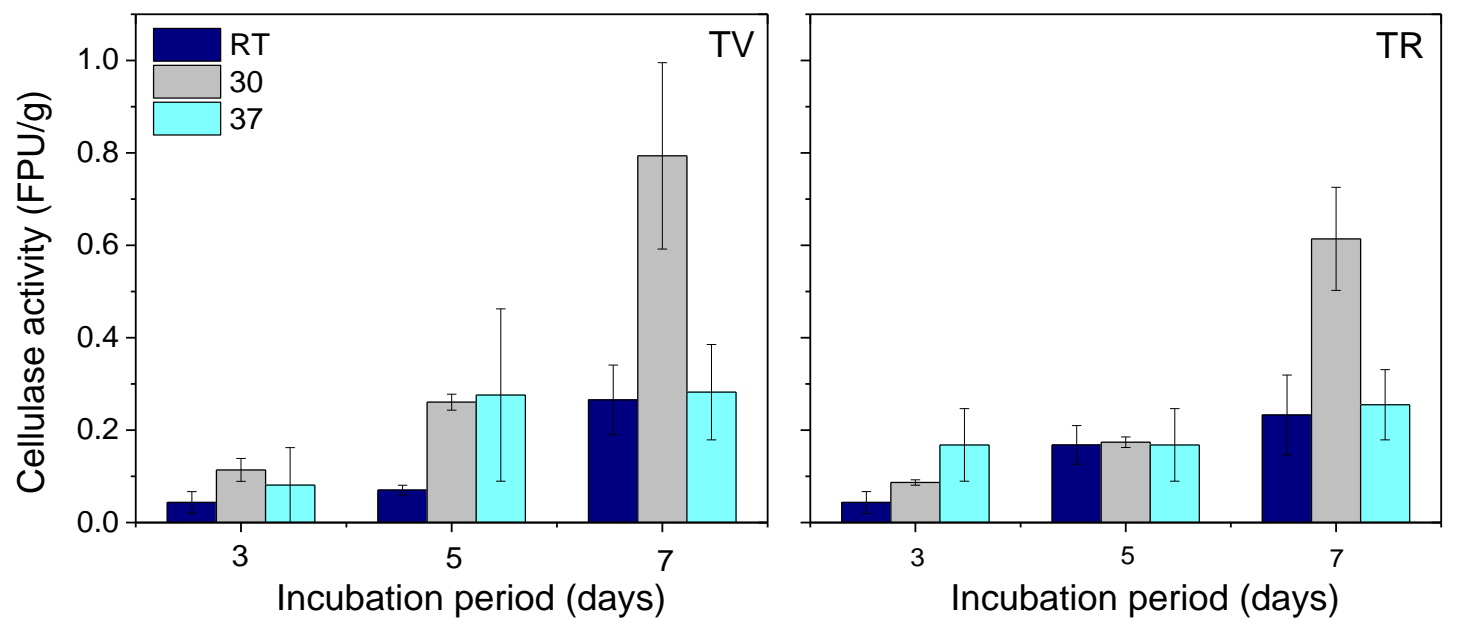

Figure 2. Cellulase activity measurement at different incubation period and temperature for TV (left) and TR (right). RT = room temperature. Initial nutrient solution pH was 5.5 and solid to liquid ratio was 1:1. Error bars indicate standard error between replicates $(n=3)$.
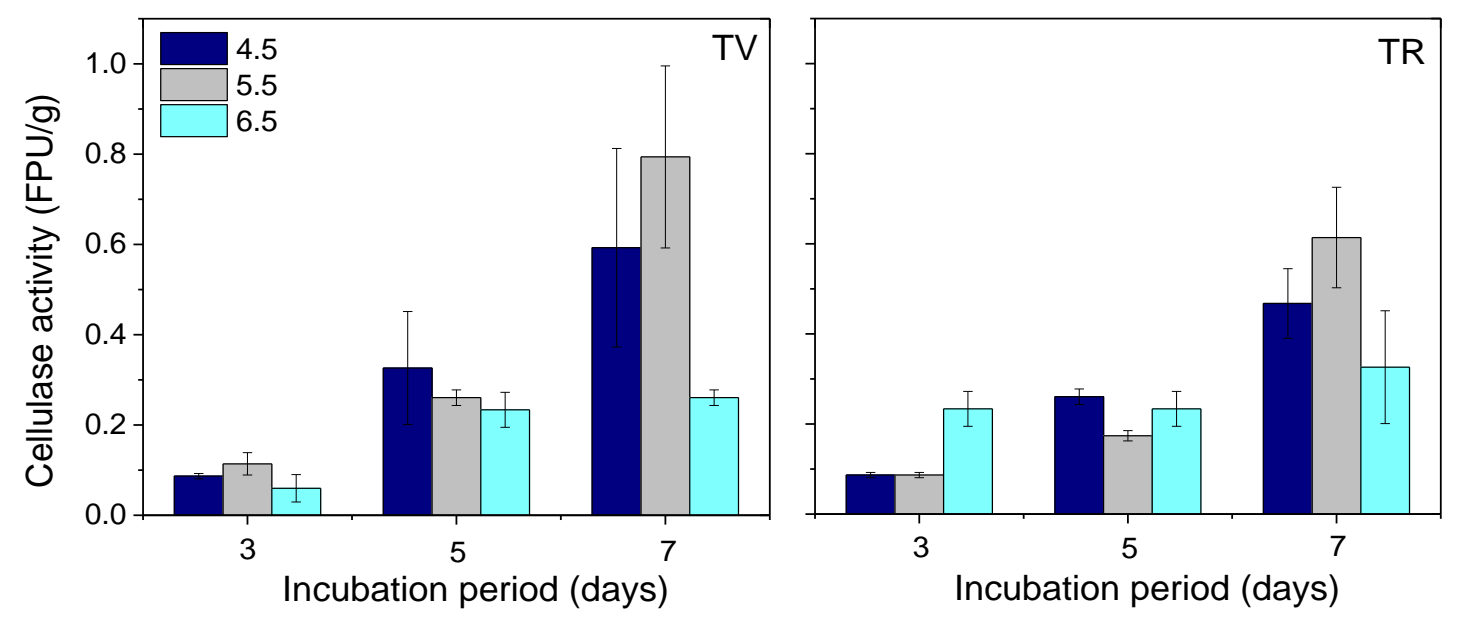

Figure 3. Cellulase activity measurement at different incubation period and pH for TV (left) and TR (right). Solid to liquid ratio was set at $1: 1$ and incubation was performed at $30{ }^{\circ} \mathrm{C}$. Error bars indicate standard error between replicates $(n=3)$. 
6.5 , the amount of cellulase were significantly lower at $0.26 \mathrm{FPU} / \mathrm{g}$ DS and $0.33 \mathrm{FPU} / \mathrm{g} \mathrm{DS}$ for TV and TR, respectively. Latifian et al. [20] and Xia and Cen [28] have reported similar observation, whereby optimum solid state fermentation for cellulase production falls within the range of $4-6$.

Cellulase production by solid state fermentation have been performed using various carbon source, such as wheat bran, dairy manure, rice straw, wheat straw, corn stove, soybean meal and corn cob [17,23,28]. When wheat bran, which is considered to be the ideal substrate for solid state fermentation, was used in solid state fermentation using Trichoderma reesei RUT C30 for producing cellulase, activity as high as 22.8 FPU/g DS can be achieved [28, 29]. Alam et al. studied the use of EFB and wheat flour mixture as solid state fermentation substrate using Trichoderma harzianum T2008 for producing cellulase and obtained crude cellulase activity of $8.2 \mathrm{FPU} / \mathrm{g}$ DS. Comparison with other reports of crude cellulase activity produced from solid state fermentation using Trichoderma showed that the result obtained here (maximum of $\sim 0.1 \mathrm{FPU} / \mathrm{mL}$ ) is considered to be low (ranging from 0.044-8.6 FPU/mL) [30].

Several methods for increasing cellulase activity in solid state fermentation has been suggested, such as better strain selection, pretreatment of the solid substrate, mixed culturing technique, and better fermenter design [5,31]. Nonetheless, the maximum cellulase activity obtained in this study is still within the typical range of cellulase activity that has been reported by Lever et al. (0.75-1.2 FPU/g DS in a system where TR was used on ground wheat straw) [30]. Importantly, Lever et al. also showed that the obtained crude cellulase enzyme can be used directly in simultaneous saccharification and bioethanol fermentation from wheat straw. Therefore, the system developed here showed high potential for production of cellulase that can be used for biomass saccharification into fermentable sugars.

\section{Conclusion}

Cellulase production by solid state fermentation of EFB was performed using two different producer organisms, namely Trichoderma viride (TV) and Trichoderma reesei (TR). Effects of different operation parameters, such as: solid to liquid ratio, temperature, and $\mathrm{pH}$, was studied in order to obtain the optimum condition for cellulase fermentation. Solid to liquid ratio of $1: 1$, temperature of $30{ }^{\circ} \mathrm{C}$, and $\mathrm{pH}$ of 5.5 was found to yield the highest cellulase activity observed here both for TV and TR. The maximum cellulase activity of $0.79 \mathrm{FPU} / \mathrm{g}$ DS was obtained when TV was used as the cellulase producers. The current study can be used as a stepping stone towards the development of an inexpensive cellulase production process from lignocellulosic waste originating from Indonesia.

\section{Acknowledgments}

This research was supported under P3MI ITB (Program Penelitian, Pengabdian kepada Masyarakat, dan Inovasi Institut Teknologi Bandung/Research Programs, Community Services, and Innovation Institut Teknologi Bandung) funding scheme.

\section{References}

[1] Yoon, L.W., Ang, T.N., Ngoh, G.C., Chua, A.S.M. (2014). Fungal Solid-State Fermentation and Various Methods of Enhancement in Cellulase Production. Biomass and Bioenergy, 67: 319-338.

[2] Ellilä, S., Fonseca, L., Uchima, C., Cota, J., Goldman, G.H., Saloheimo, M., Sacon, V., Siika, M. (2017). Development of a Low-Cost Cellulase Production Process using Trichoderma reesei for Brazilian Biorefineries. Biotechnology for Biofuels, 10: 1-17.

[3] Kuhad, R.C., Deswal, D., Sharma, S., Bhattacharya, A., Jain, K.K, Kaur, A., Pletschke, B.I., Singh, A., Karp, M. (2016). Revisiting Cellulase Production and Redefining Current Strategies Based on Major Challenges. Renewable and Sustainable Energy Reviews, 55: 249-272.

[4] Klein-Marcuschamer, D., Oleskowicz-Popiel, P., Simmons, B.A., Blanch, H.W. (2012). The Challenge of Enzyme Cost in the Production of Lignocellulosic Biofuels. Biotechnology and Bioengineering, 109: 1083-1087.

[5] Behera, S.S., Ray, R.C. (2016). Solid State Fermentation for Production of Microbial Cellulases: Recent Advances and Improvement Strategies. International Journal of Biological Macromolecules, 86: 656-669.

[6] Cerda, A., Gea, T., Vargas-García, M.C., Sánchez, A. (2017). Towards a Competitive Solid State Fermentation: Cellulases Production from Coffee Husk by Sequential Batch Operation and Role of Microbial Diversity. Science of the Total Environment, 589: 56-65.

[7] Farinas, C.S. (2015). Developments in SolidState Fermentation for the Production of Bio- 
mass-Degrading Enzymes for the Bioenergy Sector. Renewable and Sustainable Energy Reviews, 52: 179-188.

[8] Kim, S., Ho, C. (2012). Production of Cellulase Enzymes During the Solid-State Fermentation of Empty Palm Fruit Bunch Fiber. Bioprocess and Biosystems Engineering, 35: 6167.

[9] Alam, M.Z., Mamun, A.A., Qudsieh, I.Y., Muyibi, S.A, Salleh, H.M., Omar, N.M. (2009) Solid State Bioconversion of Oil Palm Empty Fruit Bunches for Cellulase Enzyme Production using a Rotary Drum Bioreactor. Biochemical Engineering Journal, 46: 61-64.

[10] Wang, Z., Ong, H.X., Geng, A. (2012) Cellulase Production and Oil Palm Empty Fruit Bunch Saccharification by a New Isolate of Trichoderma koningii D-64. Process Biochemistry, 47: 1564-1571.

[11] Nuñez-Gaona, O., Saucedo-Castañeda, G., Alatorre-Rosas, R., Loera, O. (2010). Effect of Moisture Content and Inoculum on the Growth and Conidia Production by Beauveria bassiana on Wheat Bran. Brazilian Archives of Biology and Technology, 53: 771-777.

[12] Sugiharto, Y.E.C., Harimawan, A., Kresnowati, M.T.A.P., Purwadi, R., Mariyana, R., Andry, Fitriana, H.N., Hosen, H.F. (2016). Enzyme Feeding Strategies for Better Fed-Batch Enzymatic Hydrolysis of Empty Fruit Bunch. Bioresource Technology, 207: 175-179.

[13] Chahal, D.S. (1985). Solid-State Fermentation with Trichoderma reesei for Cellulase Production. Applied and Environment Microbiology, 49: 205-210.

[14] Adney, B., Baker, J. (2008). Measurement of Cellulase Activities Laboratory Analytical Procedure.

[15] Ghose, T.K. (1987). Measurement of Cellulase Activities. Pure and Applied Chemistry, 59: 257-268

[16] Piarpuzán, D., Quintero, J.A., Cardona, C.A. (2011). Empty Fruit Bunches from Oil Palm as a Potential Raw Material for Fuel Ethanol Production. Biomass and Bioenergy, 35: 11301137.

[17] Wen, Z., Liao, W., Chen, S. (2005). Production of Cellulase by Trichoderma reesei from Dairy Manure. Bioresource Technology, 96: 491-499.

[18] Gomes, I., Shaheen, M., Rahman, S.R., Gomes, D.J. (2006). Comparative Studies on Production of Cell Wall-Degrading Hydrolases by Trichoderma reesei and T. viride in Submerged and Solid-State Cultivations. Bangladesh Journal of Microbiology, 23: 149-155.
[19] Singhania, R.R., Sukumaran, R.K., Pandey, A. (2007). Improved Cellulase Production by Trichoderma reesei RUT C30 under SSF Through Process Optimization. Applied Biochemistry and Biotechnology, 142: 60-70.

[20] Latifian, M., Hamidi-Esfahani, Z., Barzegar, M. (2007). Evaluation of Culture Conditions for Cellulase Production by Two Trichoderma reesei Mutants under Solid-State Fermentation Conditions, Bioresource Technology, 98: 3634-3637.

[21] Shahriarinour, M., Wahab, M. (2013) Effect of Medium Composition and Cultural Condition on Cellulase Production by Aspergillus terreus. African Journal of Biotechnology, 10: 7459-7467.

[22] Idris, A.S.O., Pandey, A., Rao, S.S., Sukumaran, R.K. (2017). Cellulase Production through Solid-State Tray Fermentation, and Its Use for Bioethanol from Sorghum Stover. Bioresource Technology, 242: 265-271.

[23] Vitcosque, G.L., Fonseca, R.F., RodríguezZúñiga, U.F., Neto V.B., Couri, S., Farinas, C.S. (2012). Production of Biomass-Degrading Multienzyme Complexes under Solid-State Fermentation of Soybean Meal Using a Bioreactor. Enzyme Research, vol. 2012, Article ID 248983, 9 pages. DOI: 10.1155/2012/248983.

[24] Pensupa, N., Jin, M., Kokolski, M., Archer, D.B., Du, C. (2013). A Solid State Fungal Fermentation-Based Strategy for the Hydrolysis of Wheat Straw. Bioresource Technology, 149: 261-267.

[25] Djakaria, B. (2017). Optimization of Xylanase Production Using Empty Fruit Bunches by Solid-State Fermentation in a Tray Bioreactor. Master Thesis, Department of Chemical Engineering, Institut Teknologi Bandung.

[26] Singhania, R.R., Sukumaran, R.K., Pillai, A., Prema, P., Szakacs, G., Pandey, A. (2006). Solid-State Fermentation of Lignocellulosic Substrates for Cellulase Production by Trichoderma reesei NRRL11460. Indian Journal of Biotechnology, 5: 332-336.

[27] Gomes, I., Gomes, J., Steiner, W., Esterbauer, $\mathrm{H}$. Production of Cellulase and Xylanase by a Wild Strain of Trichoderma viride. Applied Microbiology and Biotechnology, 36: 701-707.

[28] Xia, L., Cen, P. (1999). Cellulase Production by Solid State Fermentation on Lignocellulosic Waste from The Xylose industry, Process Biochemistry, 34: 909-912.

[29] Sukumaran, R.K., Singhania, R.R., Mathew, G.M., Pandey, A. (2009). Cellulase Production Using Biomass Feed Stock and its Application in Lignocellulose Saccharification for Bio-Ethanol production. Renewable Energy, 34: 421-424. 
[30] Lever, M., Ho, G., Cord-Ruwisch, R. (2010). Ethanol from Lignocellulose Using Crude Unprocessed Cellulase from Solid-State Fermentation. Bioresource Technology, 101: 70837087.
[31] Behera, A., Arora, R., Nandhagopal, N., Kumar, S. (2014). Importance of Chemical Pretreatment for Bioconversion of Lignocellulosic Biomass. Renewable and Sustainable Energy Reviews, 36: 91-106. 